\title{
Guangdong Residents' Perceptions of Chinese Dialects: A Pilot Study
}

\author{
Chuying $\mathrm{Ou}^{1}$ \\ ${ }^{1}$ School of English and Education, Guangdong University of Foreign Studies, Guangzhou, China \\ Correspondence: Chuying Ou, School of English and Education, Guangdong University of Foreign Studies, 178, \\ Waihuan Donglu, Guangzhou Higher Education Mega Center, Guangzhou 510006, China.
}

Received: August 13, 2018

Accepted: September 9, $2018 \quad$ Available online: September 20, 2018

doi:10.11114/ijsss.v6i10.3532

URL: https://doi.org/10.11114/ijsss.v6i10.3532

\begin{abstract}
Perceptual dialectology (PD) is branch of sociolinguistics which investigates ordinary people's (non-linguists) perceptions about different dialects in the language community they are living in. Most of the PD research was implemented in Europe or America, with little attention devoted to China, a country with many kinds of dialects. Applying Preston's (1981) tool for PD studies: draw-a-map task, this research analyzed dialect maps drawn from 13 respondents, who were college students from Guangdong province, China. It aimed to find out how Guangdong residents perceive Chinese dialects. There are three major findings: (1) respondents used provincial boundaries to differentiate dialect areas but did not agree on their distribution; (2) Yue dialect and Wu dialect were thought to be more pleasant; (3) respondents were concerned about economic influence on dialects and dialect protection.
\end{abstract}

Keywords: perception, perceptual dialectology, PD, Chinese dialects, non-linguists

\section{Introduction}

Perceptual dialectology (PD), a branch of folk linguistics, aims at discovering what non-linguists say about language variation. This includes "where they think it comes from, where they think it exits, and why they think it happens" (Montgomery \& Cramer, 2016). Unlike traditional dialects studies which usually focus on differences in language production (i.e. accents or lexical items), perceptual dialectology emphasizes the importance of language speakers' mental map about those differences. Collecting perceptual information can reveal the contrast between non-linguists' comprehension and actual linguistic variation (Theodoropoulou \& Tyler, 2014). This plays an essential role in "language maintenance and change" (Benson, 2003). As a major contributor and developer of PD, Preston (1981) has designed several tools for researchers to employ in PD studies (see Preston, 2010). The draw-a-map task is the most famous one among all the approaches of perceptual dialectology (Montgomery \& Cramer, 2016). With the help of a blank map, this method mainly invites participants to draw their perceived borders for the dialect areas of their community.

Although China has a set of diverse dialects, studies featuring at perceptions of Chinese dialects are highly insufficient. Researchers in China who paid attention to non-linguists' understanding of different dialects often focused on emotional attitude, for example, whether people think a certain dialect is practical (e.g. Gao, Su, \& L. Zhou, 1998; Xu \& Z. Zhou, 2016; W. Zhou, 2011), rather than the linkage between dialects and geographical features. In addition, questionnaire served as the most frequently used research tool. It may extract some general features, but does not help much in illustrating more in-depth language perceptions. Therefore, a more "interpretive and interactional approach" (Ianna 'ccaro \& Dell'Aquila, 2001) like perceptual dialectology is needed, in order to comprehensively display how non-linguists perceive language varieties. This research employed Preston's draw-a-map task and carried out a pilot PD study on Chinese dialects. Before the main study, representative research of the field will be demonstrated.

\section{Literature Review}

Recent studies about perceptual dialectology were mostly carried out in Europe and America, particularly in those linguistically complex regions. For example, in United States, Benson (2003) implemented a pilot study of 12 respondents from Ohio, using Preston' methodology of perceptual dialectology: the draw-a-map task as well as the degree-of-difference task. Benson's study verified that speakers from central and northwestern Ohio desired to preserve a distinct identity from southern Ohio and northeastern Ohio speakers. Another study was also conducted in Ohio, USA, but focused on language varieties which were based on major regional dialects in America (Yannuar, Azimova, \& 
Nguyen, 2014). Four dialects including those spoken in New York City, Ohio, Texas and Louisiana were examined. 21 Ohio university students took part in the investigation and gave opinions about the dialects' correctness, pleasantness and difference from their own speech. An impressive finding was that though Louisiana dialect ranked lowest in terms of correctness, it was thought to be the most pleasant one among the dialects. In spite of a small number of participants, both studies provided strong evidence that ordinary people's perceptions of dialects may not always be the same with linguists' expectation.

Such evidence also echoed PD research conducted in United Kingdom. In an earlier study from Williams, Garrett and Coupland (1996), secondary school teachers were required to distinguish principal dialect regions of English speech in Wales through drawing and labeling maps. The mapping they produced were found to be very different from the descriptive dialectological map of English in Wales. Such difference between actual perception and prescribed description was prominent. This was found to be related to culture in Kingstone (2015)'s research. Kingstone (2015) implemented the first and meaningful perceptual dialectology study of Scotland. He asked respondents from a northeast fishing town named Buckie to mark and give labels to dialect regions on a map. The finding was rather interesting that Scottish dialect perceptions could be categorized into three main cultural dimension: "Scottishness', the 'Good Scots/Bad Scots' distinction; 'Englishness', the cultural prominence of the Scotland-English border; and 'Foreignness', the influence of other languages on its islands". Another important study dealt with quantitative data. Pearce's (2009) study derived dialect maps from a language attitude survey involving 1,600 people across North East England. The perceptual dialect map developed from the quantitative data displayed three broad areas of perceptual landscapes and each area was divided into smaller perceptual zones. The research sites and background of participants in these studies differed from each other, but they all figured out new perceptual content of dialects, which again proved the effectiveness of PD approach.

Similar PD studies in Europe include those from Germany (Gessinger, 2010; Lam \& O'Brien, 2014), France (Boughton, 2006), Italy (Iannàccaro \& Dell'Aquila, 2001), Slovak (Maxwell, 2009), Norway (RØsstad, 2009) and Turkey (Demirci, 1998). The research showed an essential progress of the field, and again highlighted the significance of discovering how ordinary people perceive dialects. However, the overall amount of research is still far from enough, especially in countries or districts outside Europe. An exception is the survey from Theodoropoulou and Tyler (2014), who particularly investigated people's perceptions of dialects in Arab world. It embodied great value because of uncovering dialect perceptions in such a complex dialect environment.

I conducted a small-scale PD research in Guangdong province, China, in order to provide clues about how the country's residents perceive their dialects. Hopefully it would bring about a deeper understanding of dialects in China and devote to the discussion of globally perceptual dialectology studies. Here are the research questions:

(1) What do the respondents think of the boundaries and pleasantness of Chinese dialects?

(2) What opinions do the respondents hold for Chinese dialects?

\section{An Introduction of Chinese Dialect}

According to Language Atlas of China (1987,1990), the most important writing which comprehensively illustrates the distribution of Chinese dialects, there are 10 dialect areas in China. Each area can be sub-divided into more dialect regions.

Table 1. Dialect areas of China and their population (million)

\begin{tabular}{|c|c|c|c|c|}
\hline $\begin{array}{l}\text { Mandarin } \\
\text { dialects (798) }\end{array}$ & $\begin{array}{l}\text { Jin Chinese } \\
(63.05)\end{array}$ & Wu Chinese (73.79) & $\begin{array}{l}\text { Min Chinese } \\
(75)\end{array}$ & $\begin{array}{l}\text { Hakka Chinese } \\
(42.2)\end{array}$ \\
\hline $\begin{array}{l}\text { Yue Chinese } \\
(58.82)\end{array}$ & Xiang Chinese $\quad(36.37)$ & $\begin{array}{l}\text { Gan Chinese } \\
\text { (48) }\end{array}$ & Huizhou Chinese (3.3) & Pinghua \& Tuhua (7.78) \\
\hline
\end{tabular}

Table 1 presents names of these dialect areas as well as the population living in each of the areas. A revised version of the atlas in 2008 has included Tuhua into the dialect area of Pinghua. 


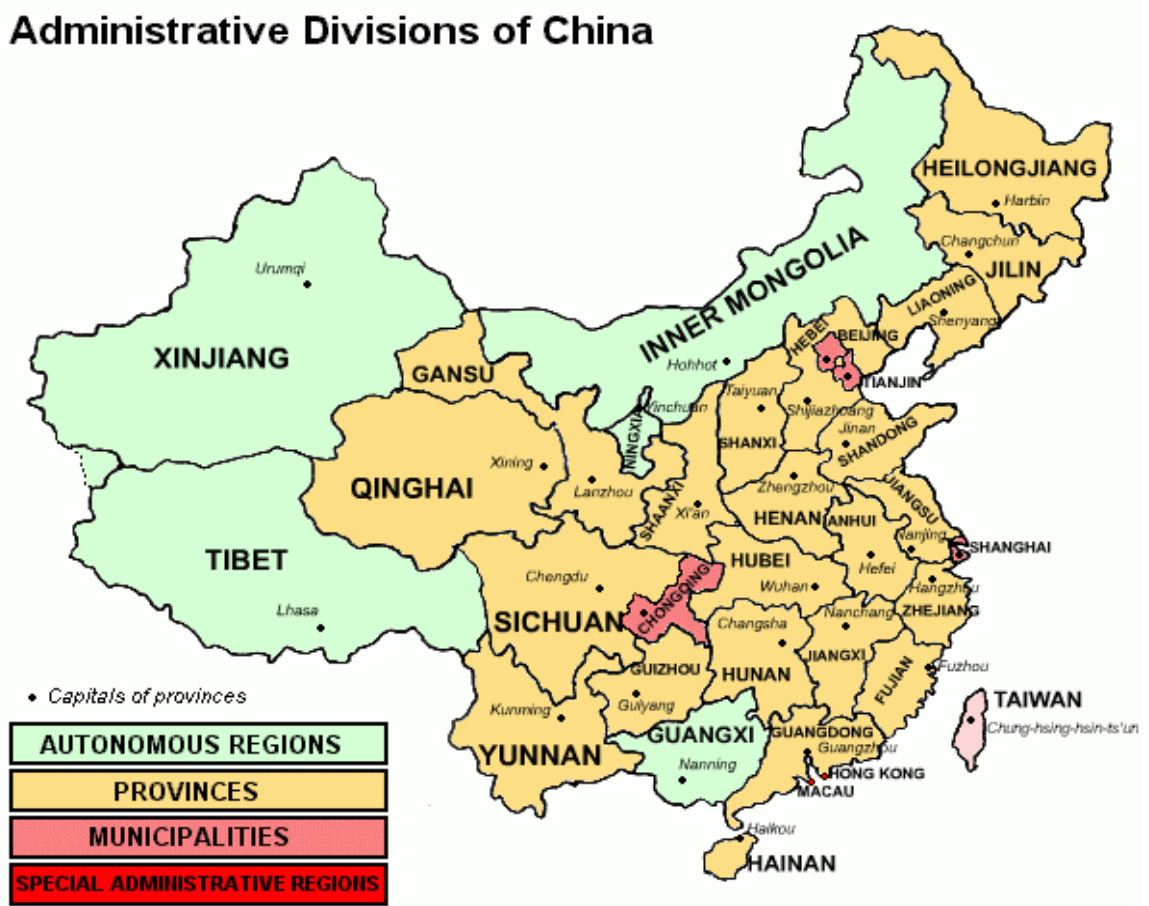

Figure 1. Administrative divisions of China

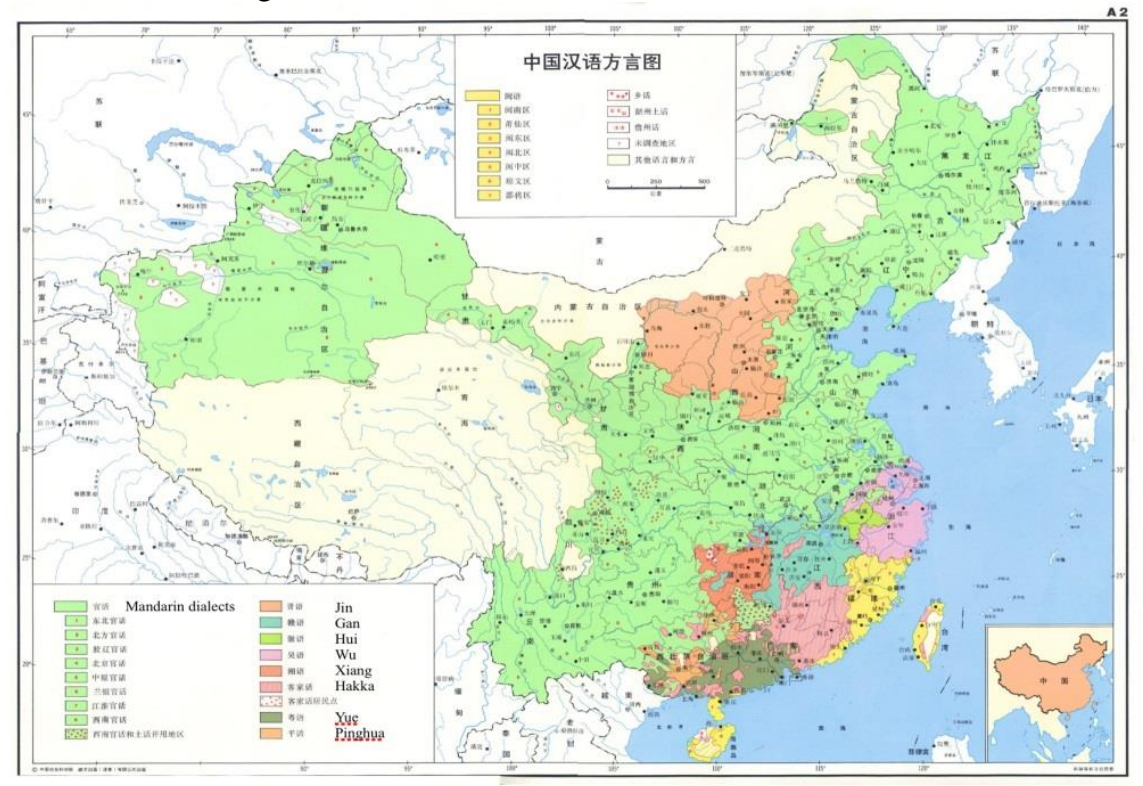

Figure 2. Dialect map of China

Figure 2 is a map of China's administrative divisions, and Figure 3 is a dialect map of China extracted from the atlas. As it is shown in the map, generally the boundaries of dialect areas are not consistent with the province borders. Southeast China has the most first-tier dialect areas. The map will be used as reference to be compared with the results of the study.

\section{Methodology and Data}

This study employed the draw-a-map task to explore how Guangdong residents perceive Chinese dialects. A map of China provided with guidance was distributed to each of the respondents. Considering their possible unfamiliarity of the provinces or districts in China, names of the provinces as well as the borders were displayed on the map (see Appendix). Participants were firstly required to draw boundaries to discriminate areas they thought people speak different dialects, and label those areas with name of dialect that belongs to it. Then they were requested to evaluate the degree of "pleasant" of the dialect areas by giving scores ranging from 1 to 10 . The higher the score was, the more pleasant that they thought the dialect sounded. Finally, they needed to write down beside the dialect areas any information they considered to be significant about the language variations. Apart from the map, they were invited to fill in some personal information as well. 
Since the research was a pilot study, the data did not involve large samples. There were altogether 14 Guangdong residents who took part in the research, and all of them were college students coming from the same university. 7 of the residents were aged from 21 to 25 , and the others were aged from 16 to 20. Only one of the respondents was male. In addition, 7 of the respondents had been living in Guangdong for about 20 years by the time the research began. The rest of them had been living in Guangdong for 1 to 6 years.

There were 14 maps collected at first but one of them was found to have missed some of the tasks. It was therefore excluded from analysis. All the respondents were told to add information about the dialects they knew as much as possible, but some of the maps turned out to be more detailed than others. Their maps will be demonstrated in findings. In addition, labels and comments made by the respondents were translated into English by the author and will be presented together with the maps.

\section{Findings}

\subsection{Dialect Boundaries}

A general observation was that the respondents distinguished different dialect regions by borders of provinces. The boundaries they created for dialect areas were just roughly overlapped with the boundaries of province-level divisions. Therefore, there were more dialect areas shown in their maps compared with the dialect map of China demonstrated above. In addition, the labels they gave for the dialect areas were often based on the names of provinces or districts.

However, it should be noticed that not all the respondents were able to write down labels for each of the areas. Only 6 of the participants could completely label all the dialect areas they clarified. There were 47 different labels defining the dialect areas in total.

Table 2. Frequently used dialect labels

\begin{tabular}{lc}
\hline Labels for dialect areas & Occurrence number \\
\hline Yueyu/ Baihua/ Guangdong hua (Yue dialect) & 11 \\
Dongbei hua (Northeast dialect) & 7 \\
Minnan hua (Minnan dialect) & 6 \\
Beijing hua/ Tianjin hua/ Beijing Tianjin hua/Jinjin hua & 5 \\
(Beijing \& Tianjin dialect) & 4 \\
Kejia hua (Hakka dialect) & 4 \\
Zang yu (Tibetan dialect) & 3 \\
Sichuan hua (Sichuan dialect) & 3 \\
Shanghai hua (Shanghai dialect) & 3 \\
Wu yu/ Jiangnan ruanyu/ Wunong ruanyu (Wu dialect) & 3 \\
\hline
\end{tabular}

Table 2 illustrates nine most frequently used dialect labels with their translation in brackets. The top three dialects which were clearly defined by the respondents were Yue dialect (often called Cantonese), Northeast dialect and Minnan dialect.

Since all the respondents were Guangdong residents, it was not surprising to find that all of them could confidently figure out Yue dialect area. Two of them did not give label to this area, but did circle out the region and gave information to it. However, respondents had different understandings about the distribution of this language. 6 of the respondents thought that only people in Guangdong province, as well as Hong Kong and Macao speak this dialect, and 5 of them held the view that both residents in Guangdong and Guangxi province speak it. 1 of them considered that Fujian, Hainan, and Taiwan province also belong to Yue dialect area. The fact is that Yue dialect is mainly spoken in Guangdong and Guangxi, not including any other provinces. 


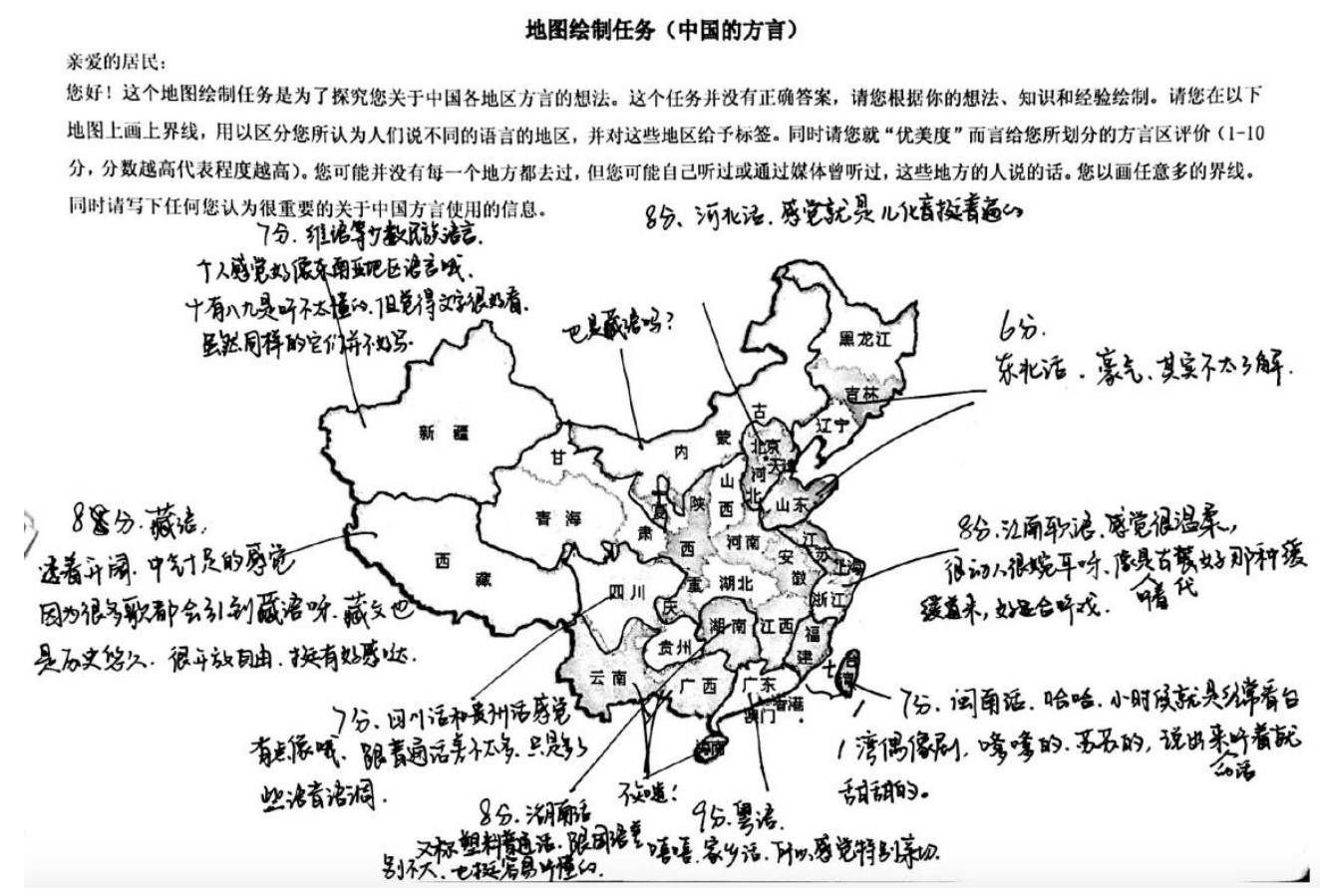

Figure 3. A map drawn by a girl born in Foshan municipality, Guangdong, who have lived in Guangdong for 20 years

Figure 3 presents a map with clear dialect boundaries. The participant thought only residents in Guangdong, Hong Kong and Macao speak Yue dialect.

Another dialect which was highly mentioned among the respondents is Northeast dialect. This dialect is one of the sub-types of Mandarin, but it turned out to be distinct to the respondents compared with other branches of Mandarin. Only one of them gave no labels or comments on this dialect. 10 out of the 13 students could almost correctly identify this dialect region, which contains three provinces that locate in northeast China: Heilongjiang, Jilin and Liaoning. One of them indicated that people in Mongolia also speak Northeast dialect, but in fact, only a small part of Mongolians do so. Another student included regions near the three northeast provinces (i.e. Beijing, Tianjin, Hebei and Shandong) into the Northeast dialect area.

Furthermore, nearly half of the respondents identified Minnan dialect affirmatively. Students agreed that Fujian and Taiwan provinces are the major regions where Minnan dialect is popular. In fact, Minnan dialect belongs to the broader Min dialect, which is also spoken by people in Hainan.

\subsection{Degree of Pleasantness}

Respondents were also required to mark the dialect areas in terms of "pleasantness" of the language. By counting the score that each respondent gave to the dialect area, I figured out the "high-score" areas and "low-score" areas within each map. However, since there were just 13 samples, data about "pleasantness" were not enough to classify the areas into "high-score" group and "low-score" group. Only some salient tendencies could be found out. First of all, most respondents suggested that Yue dialect has a high degree of "pleasantness": 10 of them gave 9 points to it on average. The positive remarks left on the map about Yue dialect indicated some of the reasons why the students thought this dialect sounds comfortable or beautiful. One of them mentioned that it has "rich pitches" so it sounds "gentle". Some of them said that it sounds "good", especially when we read out ancient poems in this dialect, because it has a kind of "rhyme" and a spirit of "classical Chinese prose". Another student thought that other than rich pitches, Yue dialect has a rather "fast speaking speed, abundant model verbs as well as prominent local characteristic". It is also easy to distinguish due to little difference between regions. However, one of the respondents pointed out that although Yue dialect sounds good, it is "difficult to learn". It should also be noticed that there was a girl who just gave "4" to this dialect regarding to degree of pleasantness. She wrote that "the 9 pitches are complicated and they do not sound good" and "don't think it sounds like singing like what others say". 


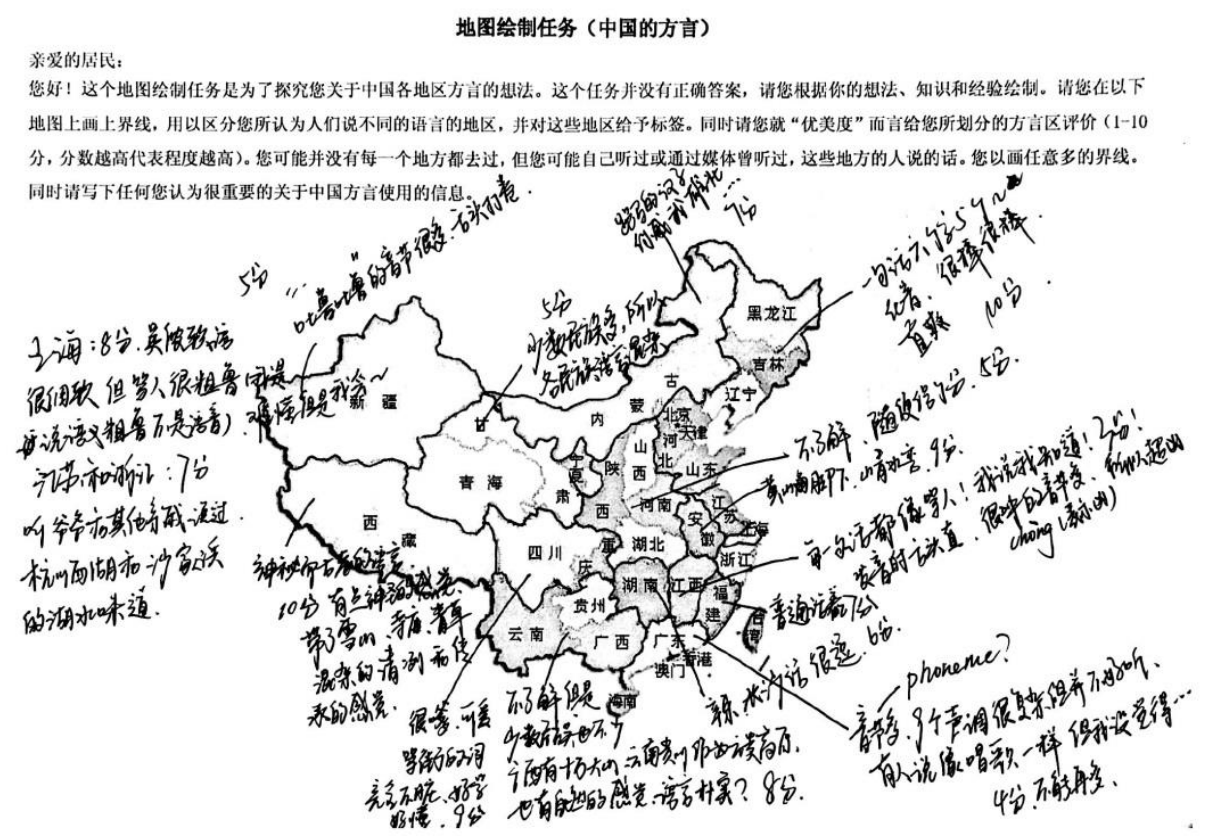

Figure 3. A map drawn by a Jiangxi-born girl who have lived in Guangdong for 1.5 years

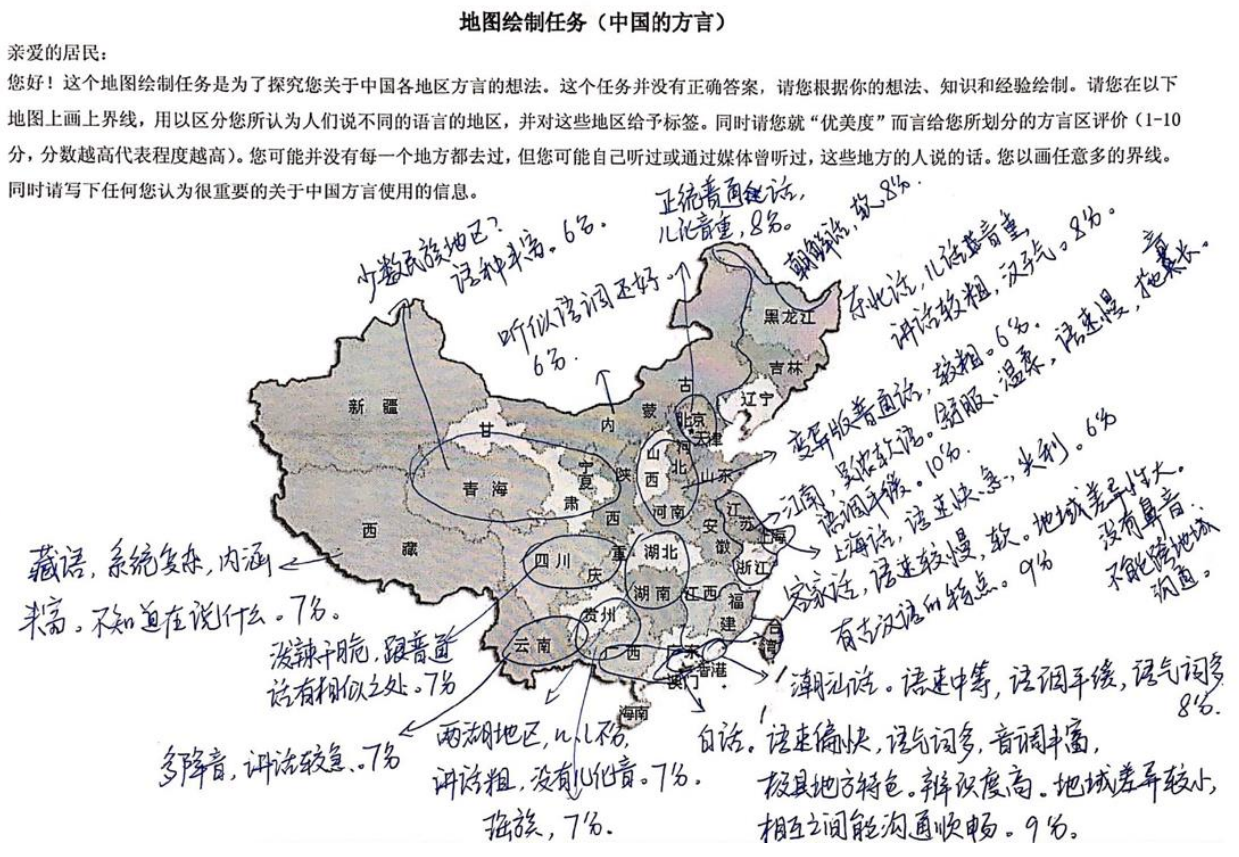

Figure 4. A map drawn by a Guangdong-born girl who has been living in Guangdong for 23 years

Figure 4 and Figure 5 presented maps drawn by two respondents. They respectively gave Yue dialect a low point (4) and a high point (9). Beside Yue dialect, respondents also thought $\mathrm{Wu}$ dialect sounds pleasant. 7 of them gave averagely 8.42 points for this dialect. They thought Wu dialect is "soft", "delegate", "comfortable" as well as "gentle". A girl mentioned that "it sounds like what is heard in costume drama which tells the story in a slow rhyme". However, like Yue dialect, there were also some respondents who held an opposite opinion. Two of the students said that Wu dialect sounds "picky" and "small-minded". Although the sample of this study was small, respondents had rather different perceptions about the pleasantness of a same dialect.

\subsection{Opinions on Dialects}

Respondents also wrote down their opinions about Chinese dialects, other than separate remarks for each dialect area. One of the girl mentioned that: "Although people in Guangzhou, Hong Kong, Zhanjiang, Maoming etc., all speak Cantonese, 
there are still great differences between the dialects they speak in terms of some common sayings, slangs and pronunciation. The more economically developed the region is, the more dialects there are in that region. And as time passing, the several dialects would integrate into one language for local communication".

亲爱的居民:

佖好！这个地图绘制任务是为了探究您关于中国各地区方言的想法。这个任务并没有正确答案, 请您根据你的想法、知识和经验绘制。请您在以下 地图上画上界线, 用以区分您所认为人们说不同的语言的地区, 并对这些地区给予标签。同时请您就 “优美度” 而言给您所划分的方言区评价 (1-10 分, 分数越高代表程度越高)。您可能并没有每一个地方都去过, 但您可能自己听过或通过媒体曾听过, 这些地方的人说的话。您以画任意多的界线。 同时请写下任何您认为很重要的关于中国方言使用的信息。

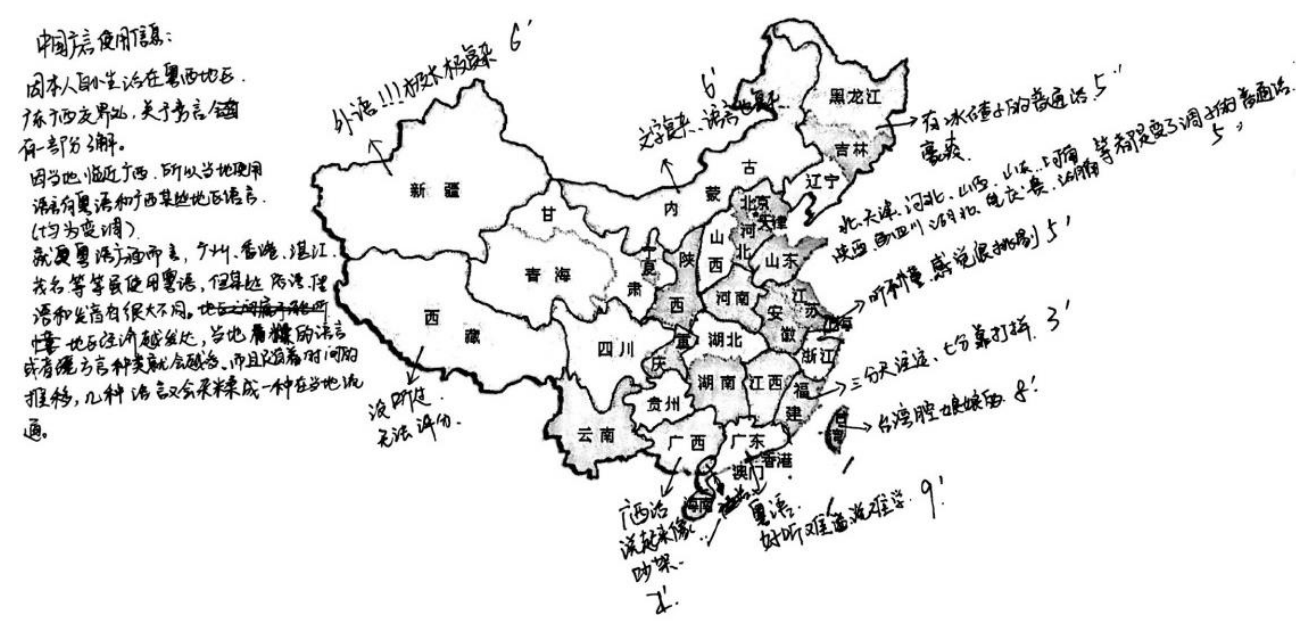

Figure 5. A map drawn by a girl born in Maoming, Guangdong, who have been living in Guangdong for 20 years

Figure 6 demonstrates this girl's comment. What the girl thought about the relationship between economy and dialects was reasonable. She probably had linked dialects with population flow, because Guangdong is a province with a large number of mobile population. The highly developed economy of Guangdong has attracted many people to seek jobs there, therefore bringing in various kinds of dialects to the province.

Another girl wrote that: "Knowing about dialects helps us to be more familiar with local culture, and accommodate to the local life. Learning about knowledge of dialects is also beneficial for the development and protection of the dialects. If we want to promote and popularize dialects, then it is necessary to make use of different tools such as writings, audios and videos to record or spread them."

One of the students worried about the same issue. She commented that "Because of the popularization of Mandarin, now many youngsters and kids do not speak dialects any more". Their comments show that other than simply expressing fondness of different dialects, the students were also concerned about the influence of economy upon these dialects as well as dialect protection.

\section{Conclusion}

Perceptual dialectology is now considered to be an indispensable part of traditional dialectology and sociolinguistic research, as it not only helps to expose "respondents' attitudes, beliefs, and identities, but also better paints the full picture of variation in and across speech communities" (Benson, 2003). By conducting Preston's draw-a-map task among 13 college students living in Guangdong, this article presents a pilot study about how Guangdong residents perceive Chinese dialects.

Overall, by adopting PD method, this research makes a contribution to the discussion of Chinese residents' perceptions of their dialects. The research firstly provides evidence that though most respondents used provincial boundaries to differentiate dialect areas, they did not agree on the scope of most specific dialect regions; the respondents thought that Yue dialect and Wu dialect were more pleasant than other dialects; respondents were concerned about the influence of economy on dialects and dialect protection. The maps they drew indicated the fact that they had rather different opinions about the dialects. Various metaphors and adjectives were used to describe their impressions upon the languages, suggesting that dialects were remembered in a great many forms.

Nevertheless, there exit some limitations in the research. As a pilot study, it has a too small number of samples, which may not well represent residents in Guangdong Province, China. A larger scale of sampling is suggested to be involved into 
future studies, so that more key features of Chinese perceptions of dialects could be figured out. Another limitation is that almost all the respondents are females, thus the research lacks feedback on males' perceptions of dialects. Prospective studies are advised to survey a balanced number of males and females. By comparing the results, they may find out gender differences in dialect perceptions.

\section{Acknowledgements}

I wish to express to my gratitude to Professor Quan Lihong for her valuable suggestions on the earlier design of this research.

\section{References}

Benson, E. J. (2003). Folk linguistic perceptions and the mapping of dialect boundaries. American Speech, 78(3), 307-330. https://doi.org/10.1215/00031283-78-3-307

Boughton, Z. (2006). When perception isn't reality: Accent identification and perceptual dialectology in French. Journal of French Language Studies, 16(03), 277. https://doi.org/10.1017/s0959269506002535

China Academy of Social Sciences, \& Australian Academy of the Humanities. (1987, 1990). 中国语言地图集 [Language Atlas of China]. Hong Kong: Longman.

Demirci, M. (1998). Gender and age-based variation in the perception of Turkish dialects. Language Awareness, 7(4), 206-222. https://doi.org/10.1080/09658419808667110

Gao, Y., Su, X., \& Zhou, L. (1998). 回归前香港、北京、广州的语言态度 [The language attitude of citizens in Hong Kong, Beijing and Guangzhou before the return of Hong Kong to China]. Foreign Language Teaching and Research, 2, 21-28.

Gessinger, J. (2010). Language variation, language change and perceptual dialectology. Multilingua - Journal of Cross-Cultural and Interlanguage Communication, 29(3-4), 361-383. https://doi.org/10.1515/mult.2010.018

Iannàccaro, G., \& Dell'Aquila, V. (2001). Mapping languages from inside: Notes on perceptual dialectology. Social \& Cultual Geography, 2(3), 265-280. https://doi.org/10.1080/14649360120073851

Kingstone, S. (2015). "Scottish", "English” or “foreign": Mapping Scottish dialect perceptions. English World-Wide, 36(3), 315-347. https://doi.org/10.1075/eww.36.3.02kin

Lam, H., \& O'Brien, M. G. (2014). Perceptual dialectology in second language learners of German. System, 46, 151-162. https://doi.org/10.1016/j.system.2014.08.006

Maxwell, A. (2009). Why the Slovak language has three dialects: A case study in historical perceptual dialectology. Austrian History Yearbook, 37, 141. https://doi.org/10.1017/s0067237800016817

Ministry of Education, China. (2015). An overview of Chinese languages. Retrieved from http://old.moe.gov.cn//publicfiles/business/htmlfiles/moe/s5990/201111/126551.html

Montgomery, C., \& Cramer, J. (2016). Developing methods in perceptual dialectology. In J. Cramer \& C. Montgomery (Eds.), Cityscapes and Perceptual Dialectology: Global Perspectives on Non-Linguists' Knowledge of the Dialect Landscape (pp. 9-24): De Gruyter.

Pearce, M. (2009). A perceptual dialect map of North East England. Journal of English Linguistics, 37(2), 162-192. https://doi.org/10.1177/0075424209334026

Preston, D. R. (1981). Perceptual dialectology: Mental map of the United States dialects from a Hawaiian perspective (summary). In H. Warkentyne (Ed.), Methods IV (Papers from the Fourth International Conference on Methods in Dialectology), (pp. 192-198). Victoria, BC: University of Victoria.

Preston, D. R. (2010). Language, people, salience, space: perceptual dialectology and language regard. Dialectologia: revista electronica, (5), 87-131.

R $\oslash$ sstad, R. (2009). Foundations of language perceptions and the role of external factors: a Norwegian case. Language Awareness, 18(2), 96-112. https://doi.org/10.1080/09658410802510146

Theodoropoulou, I., \& Tyler, J. (2014). Perceptual dialectology of the Arab world: A principal analysis. Journal of the American Association of Teachers of Arabic, 47, 21-39.

Williams, A., Garrett, P., \& Coupland, N. (1996). Perceptual dialectology, folklinguistics, and regional stereotypes: Teachers' perceptions of variation in Welsh English. Multilingua - Journal of Cross-Cultural and Interlanguage Communication, 15(2), 171-200. https://doi.org/10.1515/mult.1996.15.2.171

Xu, H., \& Zhou, Z. (2016). 广州青少年语言使用与语言态度调查与分析 [On language use and language attitude of 
the youths and adolescents in Guangzhou]. Applied Linguistics, 3, 20-29. https://doi.org/10.16499/j.cnki.1003-5397.2016.03.003

Yannuar, N., Azimova, K., \& Nguyen, D. (2014). Perceptual Dialectology: Northerners and Southerners' View of Different American Dialects. K@ta: A Biannual Publication on the Study of Language and Literature, 16(1), 8-14.

Zhou, W. (2011). 语言态度和语言使用的相关性分析一以 2007 年南京城市语言调查为例 [The relationship between language attitudes and language uses: Taking 2007's Nanjing urban language survey for example]. Language Teaching and Linguistic Studies, 1, 89-96.

\section{Appendix}

Draw-a-map task: perceptions of Chinese dialects from Guangdong residents

亲爱的居民:

地图绘制任务 (中国的方言)

您好! 这个地图绘制任务是为了探究您关于中国各地区方言的想法。这个任务并没有正确答案, 请佨根据你的想法、知识和经验绘制。请您在以下 地图上画上界线, 用以区分您所认为人们说不同的语言的地区, 并对这些地区给予标签。同时请您就 “优美度” 而言给您所划分的方言区谈价 (1-10 分, 分数越高代表程度越高)。您可能并没有每一个地方都去过, 但您可能自己听过或通过媒体曾听过, 这些地方的人说的话。您以画任意多的界线。 同时请写下任何您认为很重要的关于中国方言使用的信息。

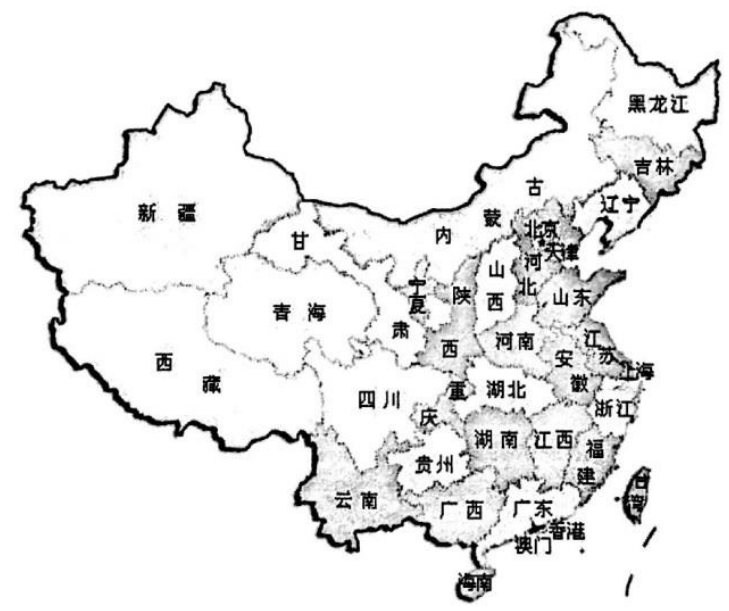

\section{请您同时填写或勾选以下个人信息:}

$\begin{array}{lllllll}\text { 1. 年龄 (岁): } 10-15 & 16-20 & 21-25 & 26-30 & 30-40 & 40-50 & 50 \text { 以上 }\end{array}$

2. 性别: 男 女

3. 您在广东居住了多少年?

4. 您的籍贯是?

5. 您的家乡话是?

6. 您的民族是?

7. 您的职业是?

8. 您的最高学历是?

9. 您会说的外语是? 
Translation:

Dear residents:

This draw-a-map task is designed to explore your ideas about the different dialects of China. There is no correct answer for this task so you just need to finish it based on your own thoughts, knowledge and experience. Please draw boundaries on the map to distinguish the areas that you think they speak different languages and give labels for each of the areas emerge. At the same time, please evaluate the degree of "pleasant" for the dialect areas ( 1 to 10 points, the higher the more pleasant). You may not have been to every place in the map but you probably have heard speakers by yourselves or through the media. Please draw as many boundaries as you want to draw and write down any information that you think it is important about the use of Chinese dialects.

Please also fill in the personal information below:

1. Age: $10-15 \quad 16-20 \quad 21-25 \quad 26-30 \quad 30-40 \quad 40-50$ more than 50

2. Gender: male female

3. How many years have you been living in Guangdong?

4. Where's your hometown?

5. Which dialect do you speak?

6. What's your ethnic group?

7. What's your job?

8. What's your highest academic qualification?

9. What foreign languages can you speak?

\section{Copyrights}

Copyright for this article is retained by the author(s), with first publication rights granted to the journal.

This is an open-access article distributed under the terms and conditions of the Creative Commons Attribution license which permits unrestricted use, distribution, and reproduction in any medium, provided the original work is properly cited. 